EESTI NSV TEADUSTE AKADEEMIA TOIMETISED 1954. III kd., nr. 4 ИЗВЕСТИЯ АКАДЕМИИ НАУК ЭСТОНСКОИ ССР 1954. ТоМ III, № 4

\title{
УСВОЯЕМОСТЬ АЗОТА (ПРОТЕИНА) КОРМА МОЛОДНЯКОМ КРУПНОГО РОГАТОГО СКОТА ЭСТОНСКОЙ КРАСНОЙ ПОРОДЫ
}

\author{
п. Я. АРАНДИ, \\ кандидат сельскохозяйственных наук
}

Обмен азота и биологическая ценность рационов изучались нами в Институте животноводства и ветеринарии Академии наук Әстонской ССР у тех же групп молодняка, с которыми велись опыты по переваримости корма $\left({ }^{1}\right)$ и при тех же типах кормления, т. е. с молодняком пяти групп в возрасте $1,3,6,9-10,12,18-21$ и 24 месяцев (V группа - до годовалого возраста), при рационах весьма различной структуры и различного состава.

В первом периоде опытов, проведенных с телятами месячного возраста, азот рационов использовался животными I и II группы, которым скармливалось по 8-12 кг цельного молока в сутки, на $10-22 \%$ лучше (56$66 \%$ к съеденному в корме), чем животными других групп (табл. 1, рис. 1). Слабое усвоение протеина телятами III группы (44\% от принятого в корме) наблюдалось при умеренных дачах цельного молока (6 кг в сутки) и при отсутствии в рационах высококачественных грубых и сочных кормов.

По усвоению азота особое положение занимали животные V группы, в рационах которых протеин молока составлял лишь $57 \%$, в то время как в рационах других групп он составлял почти $100 \%$. Остальная часть протеина была им дана в овсяной муке, в виде болтушки, в сене и корнеплодах. По сравнению с телятами I и II группы они использовали протеин значительно хуже, но все же лучше, чем молодняк III группы. Лучшая ассимиляция протеина телятами V группы объясняется значительно бо́льшим содержанием его в рационах и более высоким уровнем кормления.

У молодняка III группы, ввиду заниженного уровня кормления, часть протеина, которая могла быть использована для построения тканей организма, подвергалась, повидимому, дезаминированию и использовалась лишь для удовлетворения энергетических потребностей животных.

Биологическая ценность протеина рационов устанавливалась при помощи рекомендованной проф. И. С. Поповым $\left({ }^{10}\right)$ формулы:

коэффициент использования $=\frac{\mathrm{N} \text { корма }-\mathrm{N} \text { кала }-\mathrm{N} \text { мочи }}{\mathrm{N} \text { корма }-\mathrm{N} \text { кала }}-100$. 


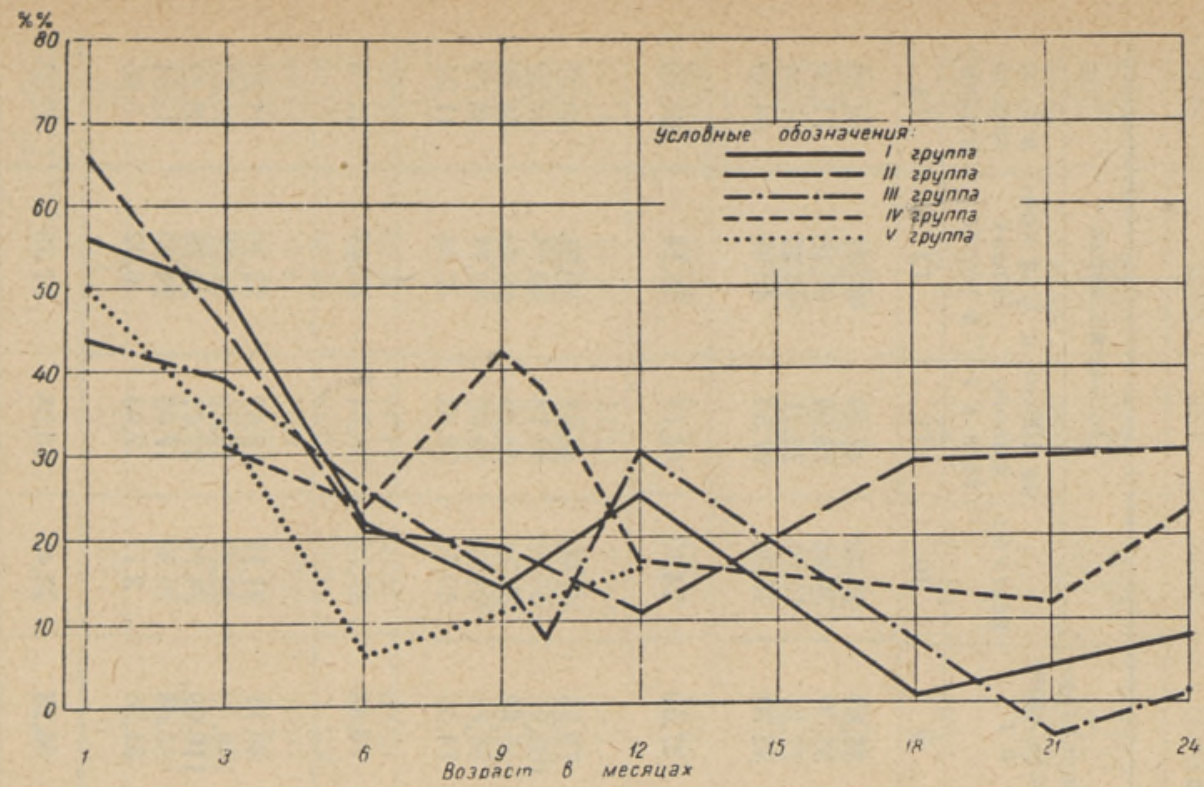

Рис. 1. Использование азота.

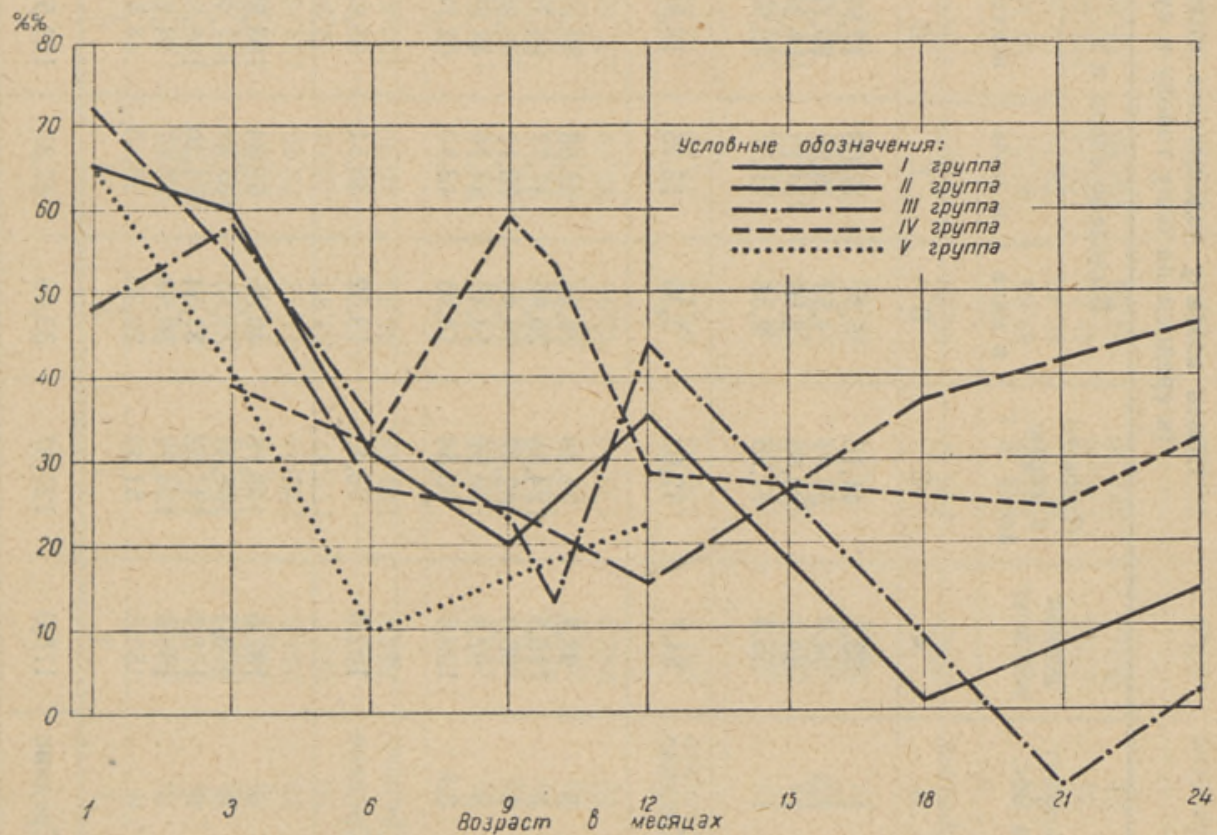

Рис. 2. Биологическая ценность протеина.

Коэффициент использования протеина рационов у молодняка I и V группы оказался практически равным (65\%), превышая этот же показатель у молодняка III группы почти на $20 \%$ (рис. 2).

Большое влияние на ассимиляцию протеина 3-месячными телятами оказывало количество легкоусвояемого животного протеина, который молодняк получал в выпоенном снятом молоке. Так, в рационах животных I группы (10 кг обрата, смесь концентратов, вволю грубых и сочных кор- 


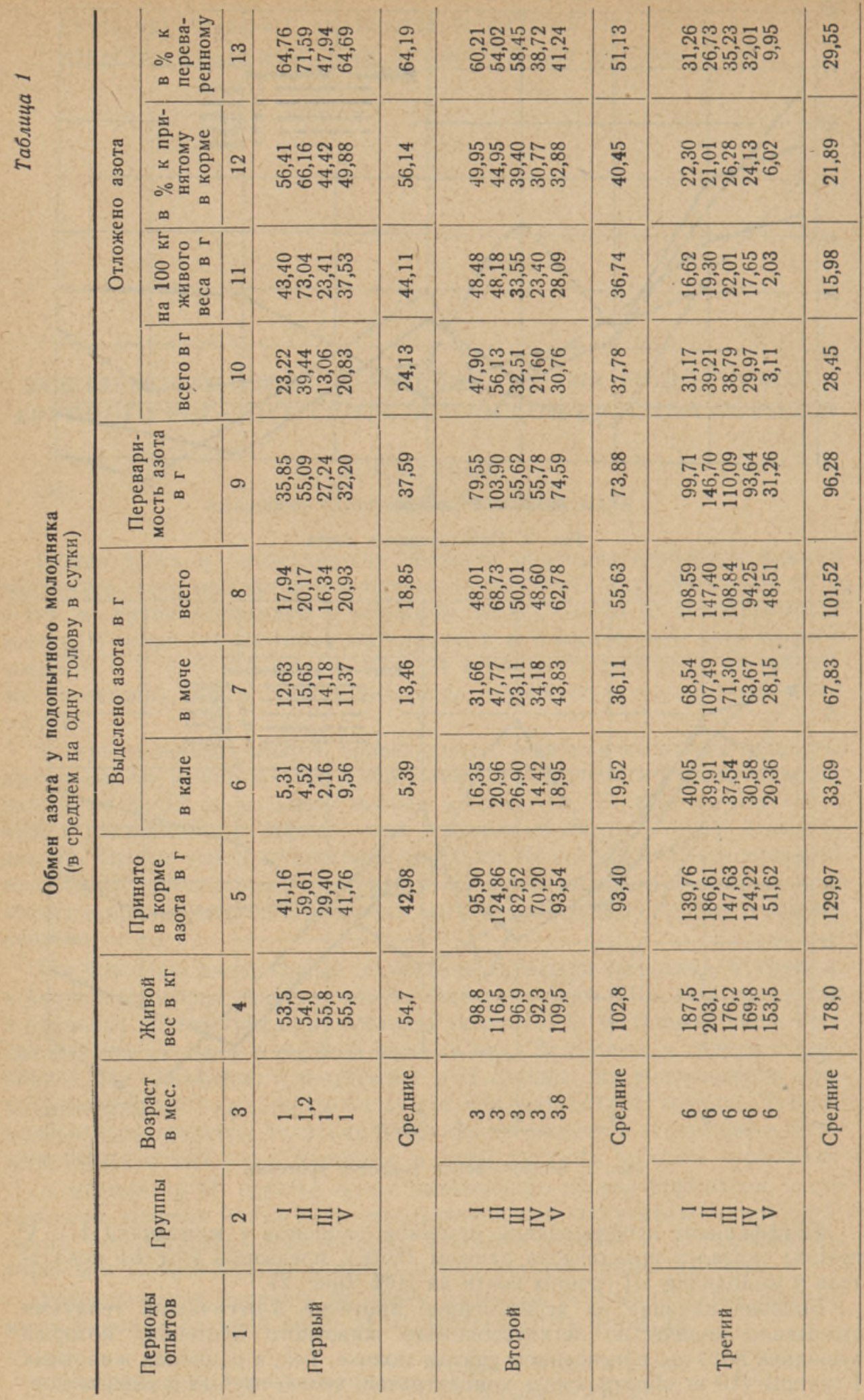




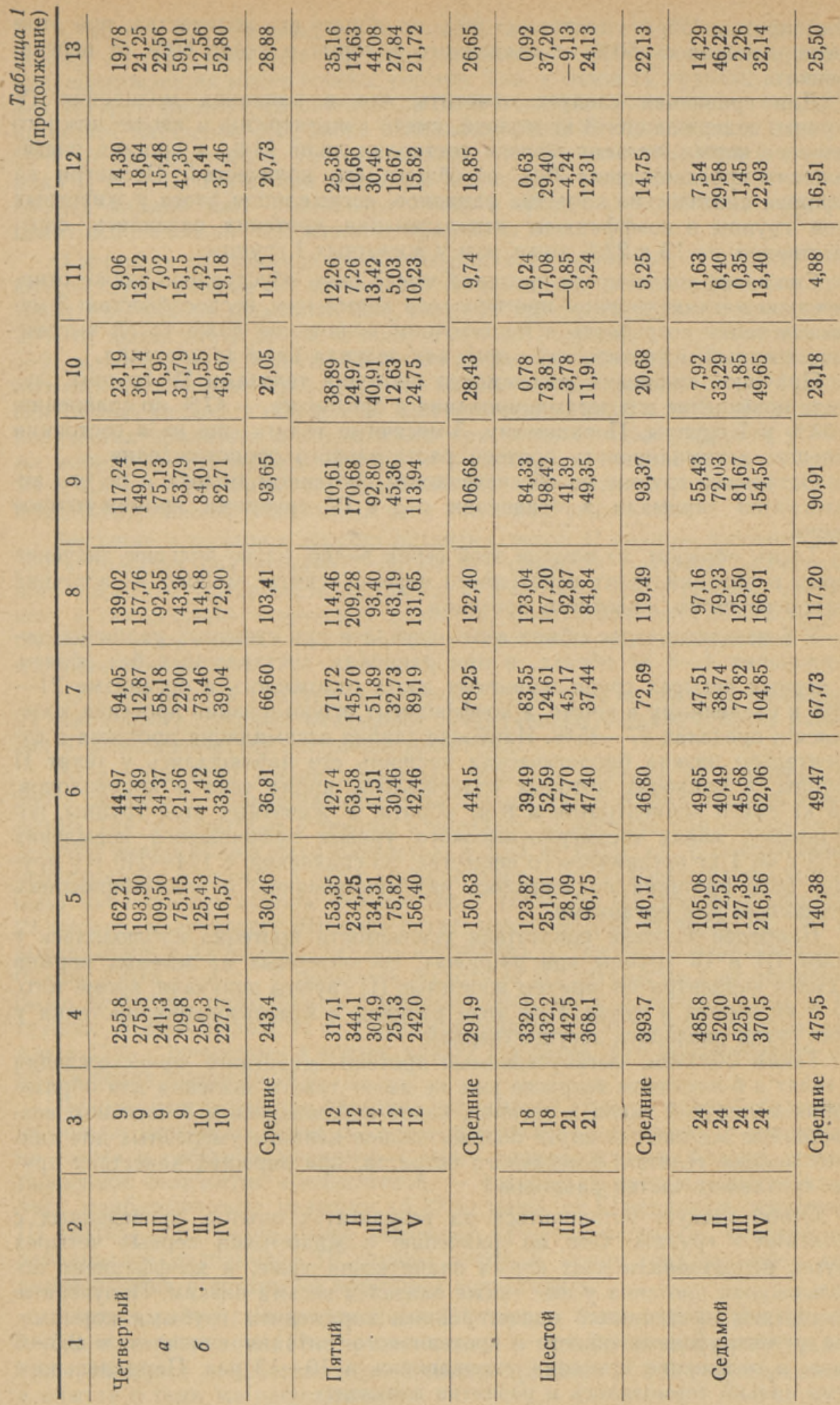


мов) протеин обрата составлял $66 \%$ от общего его количества; при этом азота отложилось $50 \%$ от съеденного в корме и около $60 \%$ от переваренного.

Для сравнения следует отметить, что в рационах молодняка IV группы, содержавших 3 кг молока, смесь концентратов и вволю нежного зеленого корма, протеин молока составлял лишь $21 \%$, а протеин растительного происхождения $79 \%$ от общего его количества. Несмотря на хорошие диэтические качества рационов, ассимиляция азота у животных этой группы и коэффициент использования протеина оказались, соответственно, на 19 и $22 \%$ ниже, чем у животных I группы.

Снижение усвояемости протеина могло быть обусловлено также относительно низким уровнем протеинового кормления, неспособностью 3-месячных телят потреблять в достаточном количестве даже такой высококачественный и диэтический корм, как зеленая вика до цветения.

Причиной снижения усвояемости протеина телятами IV группы служило повышение его дезаминирования в организме - $47 \%$ по сравнению c $33 \%$ у I группы. Повидимому, 3-месячные телята еще не в состоянии успешно ассимилировать протеин растительного происхождения.

Остальные группы по обеспеченности протеином молока и по его ассимиляции занимали в сравнении с I и IV группами промежуточное место.

Таким образом, из опытов этой серии видно, какое большое значение имеет в питании телят переходного периода снятое молоко - источник легкоусвояемого животного протеина.

У 6-месячных телят обмен азота изучался при суточных рационах, содержавших 4-8 кг обрата, и при рационах, составленных без обрата. У первых четырех групп животных азота отложилось в организме $21-$ $26 \%$ к съеденному в корме, а коэффициент использования протеина колебался в пределах $27-35 \%$. Наиболее слабая ассимиляция протеина и относительно низкая биологическая ценность его наблюдались у телят II группы, в рационах которых содержалось, кроме сена и корнеплодов, 2,5 кг смеси концентратов и 8 кг обрата. У животных этой группы, повидимому, ввиду чрезмерно высокого уровня протеинового кормления (252 г на 1 кг органического вещества, по сравнению с $124-215$ г у других) $58 \%$ протеина подвергалось дезаминированию и элиминировалось без пользы для организма.

Наиболее высокие показатели усвояемости протеина наблюдались у телят III и IV группы при рационах, составленных из зеленых кормов и смеси концентратов, причем животные III группы получали, кроме того, по 5 кг обрата в сутки. При этом разница в использовании протеина у этих групп оказалась несущественной.

Таким образом, легкоусвояемый протеин животного происхождения у телят в 6-месячном возрасте уже не имеет такого значения для образования мышечной ткани и органов, какое наблюдалось в 3-месячном возрасте. Все же опыт показал положительное влияние умеренных дач снятого молока телятам 6-месячного возраста, при хороших качествах других составных частей рашионов.

Особо следует остановиться на результатах опытов, проведенных с телятами V группы. Они, по сравнению с животными первых четырех групп, использовали азот корма значительно хуже, и коэффициент использования протеина у них также оказался весьма низким. Полученные результаты объясняются односторонним кормлением грубыми кормами, ввиду чего уровень общего и протеинового питания снизился в 2,5-3 раза, а отложение протеина уменьшилось в $10-13$ раз. Параллельно с этим сильно тормозилось и развитие животных. 
В опытах, проведенных с молодняком в возрасте 9-12 месяцев, обращает на себя внимание хорошая усвояемость протеина зимних рационов, содержавших много сочных кормов. Так, у телок IV группы, в рационах которой корнеплоды составляли $52 \%$ и высококачественное сено $48 \%$ по общей питательности, азота отложилось $42 \%$ от принятого в корме и $59 \%$ от переваренного. Для сравнения следует отметить, что у молодняка I, II и III групп при рационах с малым и умеренным количеством сочных кормов азот усваивался лишь в пределах $8-19 \%$, а коэффициент использования протеина не превышал $24 \%$.

O хороших диэтических свойствах рационов животных IV группы свидетельствуют данные об интенсивности процессов дезаминирования протеина в организме животных. Так, телки IV группы выделяли в моче азота $29 \%$ от принятого в корме, а животные I и II группы - приблизительно $58 \%$, или в два раза больше. После исключения из рационов IV группы соч. ных кормов, усвоение протеина и его биологическая ценность при безконцентратных рационах снизились, соответственно, на 26 и $31 \%$. Из равного количества принятого в корме азота при первых типах рационов у этих же животных отложилось 32 г азота в сутки, при вторых типах - лишь 13 г. Следует отметить, что при большом количестве в рационах корнеплодов потребление животными сена несколько снижалось.

Введение в рационы хорошо развитых телок II группы годового возраста больших дач концентратов (3 кг) служило причиной значительного снижения усвояемости протеина. У животных же V группы, отставших в предыдущие периоды в развитии, увеличение питательности рационов и содержания в них протеина сопровождалось повышением ассимиляции протеина.

Из этих опытов следует, что, кроме структуры и состава рационов, на усвояемость протеина оказывают существенное влияние степень развития и физиологическое состояние животных.

Во втором году жизни животных большое влияние на усвояемость азота оказывало количество протенна в рационах и общий уровень кормления. Так, у животных I группы в возрасте 18 месяцев при рационах из зеленой травы общей питательностью в 4,72 кг корм. ед. с содержанием переваримого протеина в 527 г (определялся в опытах на этих же животных) наблюдалось азотное равновесие. У телок же III группы в возрасте 21 месяца, получавших рационы питательностью 5,58 кг корм. ед. (30 кг корнеплодов и 3,8 кг сена, без концентратов), установился отрицательный баланс азота $(-4$ г). В рационах животных III группы на 1 кг органического вещества приходилось протеина лишь на 6 г меньше, чем у IV группы - 85 г против 91 г. Притом у животных IV группы отложилось азота $12 \%$ к принятому в корме, или 12 г в сутки, при коэффициенте использования протеина $24 \%$.

Лучшее использование протеина телками IV группы можно объяснить не только несколько более высоким содержанием протеина в рационах, но также и составом рационов - смесь сочных кормов, больше сена и умеренное количество концентратов, - которые по питательности оказались приблизительно равными (5,37 кг корм. ед.) рационам животных III группы. Благодаря более высокому качеству рационов, протеин переваривался молодняком IV группы лучше и, кроме того, процессы дезаминирования в организме животных сократились.

Азотное равновесие у животных III группы было достигнуто при содержании в рационах 128 г протеина на 1 кг органического вещества или при суммарном количестве переваримого протеина в 510 г (установлено в опытах с теми же животными). 


\begin{tabular}{|c|c|c|c|c|c|}
\hline \multirow{4}{*}{ 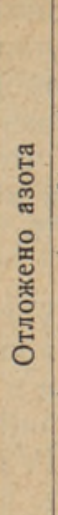 } & 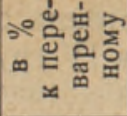 & $\dddot{m}$ & 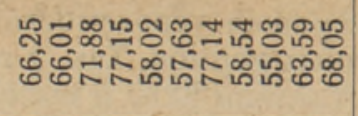 & 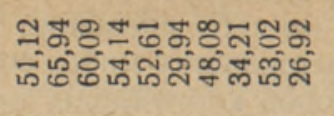 & के \\
\hline & \multicolumn{2}{|c|}{ 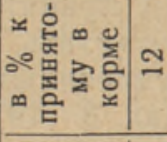 } & 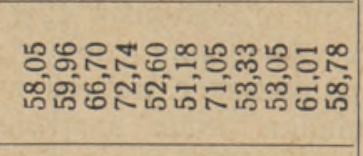 & 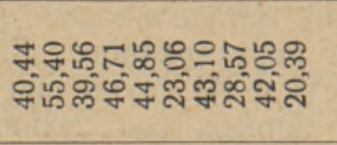 & 8 \\
\hline & 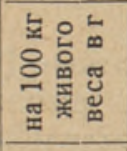 & $=$ & 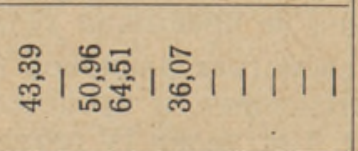 & 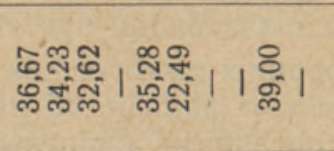 & \\
\hline & 怤 & 으 & 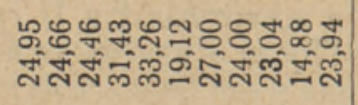 & 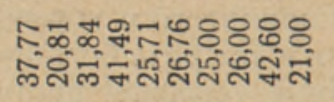 & 5 \\
\hline \multicolumn{2}{|c|}{ 涋。怘 } & os & 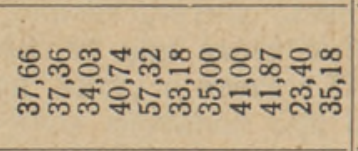 & 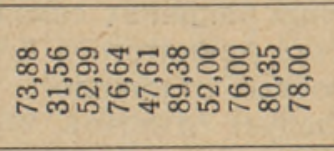 & $\begin{array}{l}\text { సે } \\
\text { ĥ }\end{array}$ \\
\hline \multirow{3}{*}{ 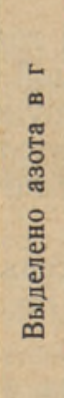 } & 잃 & $\infty$ & 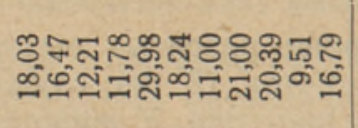 & 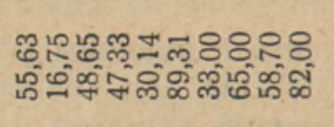 & $\stackrel{ }{=}$ \\
\hline & $\frac{\dddot{\Xi}}{2}$ & 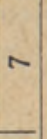 & 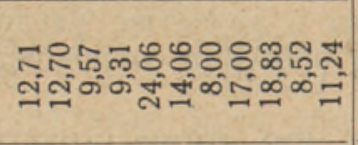 & 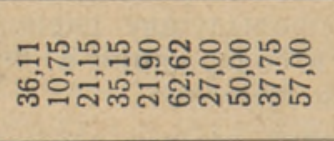 & @् \\
\hline & 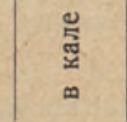 & $\omega$ & 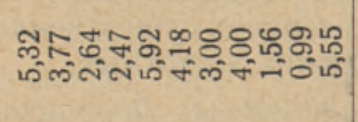 & 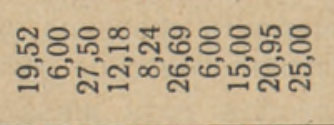 & : \\
\hline \multicolumn{2}{|c|}{ 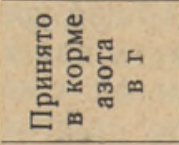 } & 10 & 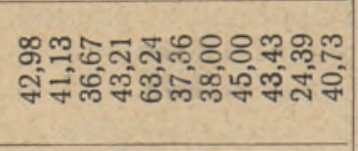 & 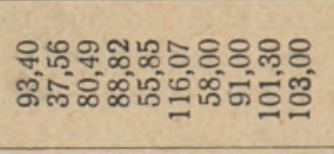 & $\begin{array}{l}\mathscr{8} \\
\infty\end{array}$ \\
\hline \multicolumn{2}{|r|}{ 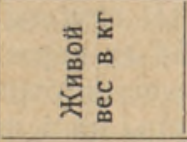 } & $\theta$ & ผ̊ & 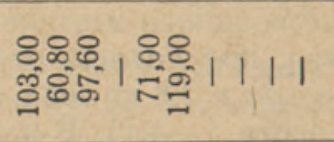 & \\
\hline \multicolumn{2}{|r|}{ 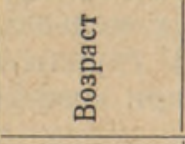 } & ๓ & 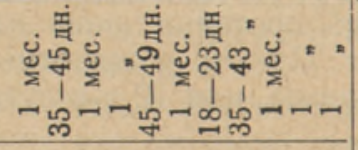 & \multicolumn{2}{|c|}{ 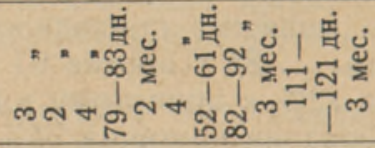 } \\
\hline \multicolumn{2}{|c|}{ 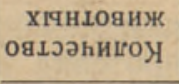 } & $\sim$ & ๑ & 으는 & \\
\hline & 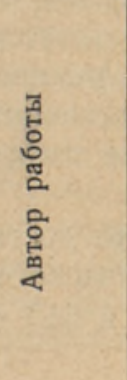 & - & 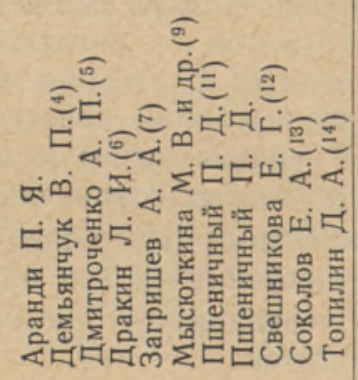 & 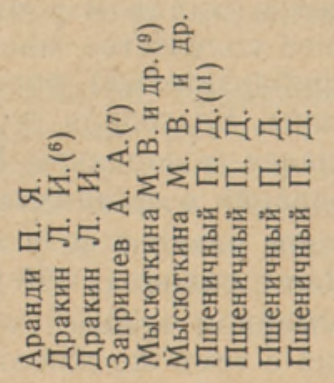 & 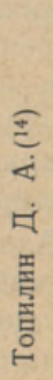 \\
\hline
\end{tabular}




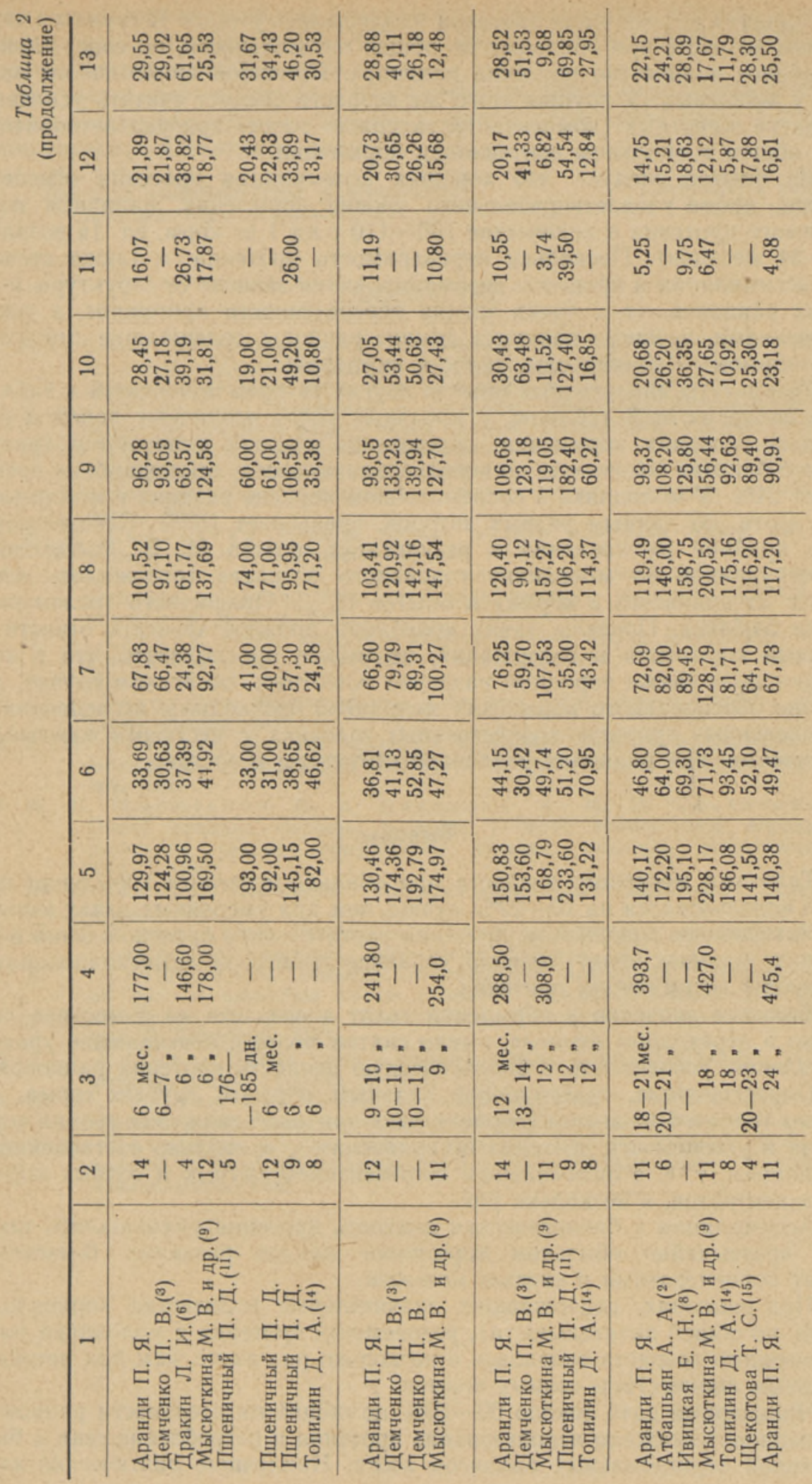


Хорошая ассимиляция протеина наблюдалась у телок II группы в двухлетнем возрасте при обильных по общей питательности, но содержавших умеренное количество протеина рационах. Причиной аналогичного явления у животных IV группы этого же возраста следует считать усиленное развитие животных (компенсация задержки роста) при удовлетворительном общем и обильном протеиновом кормлении.

Из опытов следует, что хорошая ассимиляция протеина обеспечивается, кроме удовлетворительного уровня кормления, наличием переваримого протеина в количестве $100-110$ г на 1 кг корм. ед. (в возрасте 18 -24 месяцев). Поскольку переваримость протеина, а также степень его ассимиляции и процессы дезаминирования зависят от структуры и состава рационов, то, с точки зрения обеспеченности протеином, а также витаминами, лучшими являются зимние рационы, содержащие смесь сочных кормов - корнеплоды, силос и картофель.

Результаты аналогичных опытов других авторов приводятся в табл. 2. Как видно из этой таблицы, у месячных телят различных пород в различных условиях кормления, содержания и ухода отмечаются сравнительно близкие показатели по использованию азота; отклонения не превышают $24 \%$. У молодняка в послемолочном периоде разница в использовании азота, по данным разных авторов, превышает $100 \%$. Следует отметить крайние расхождения в результатах опытов $M$. В. Мысюткиной и сотрудников по молодняку годовалого возраста (отложилось азота $6,82 \%$ от принятого в корме) и опытов П. Д. Пшеничного (отложилось азота $54,54 \%$ ). Пределы таких колебаний должны зависеть отчасти от режима кормления и содержания, но можно предполагать, что в этом играют роль также породные различия животных. Во всяком случае, для научно обоснованного кормления молодняка необходимы исследования в определенных природно-хозяйственных условиях, с местными животными и кормами, при рационах различной структуры и состава.

\section{Выводы}

Телятами месячного возраста при обильно-молочном кормлении протеин использовался на $10-22 \%$ лучше, чем при умеренных дачах молока.

Завышенное содержание протеина растительного пронсхождения в рационах молодых телят вызвало усиление процессов дезаминирования и снижение ассимиляции протеина.

Большое значение в кормлении телят в возрасте до 6 месяцев; особенно в переходном периоде, имело снятое молоко, повышавшее уровень кормления, усвояемость и биологическую ценность протеина рационов.

Односторонние, содержавшие главным образом грубые корма, рационы телят в 6-месячном возрасте были причиной снижения уровня кормления и усвояемости протеина по сравнению с правильно составленными рационами, т. е. с оптимальным соотношением грубых и сочных кормов и концентратов, в несколько раз.

Ассимиляция и биологическая ценность протеина уменьшались также при чрезвычайно обильном кормлении хорошо развитых 6-месячных телят концентратами и снятым молоком.

При рационах, содержавших значительные количества корнеплодов (50\% по общей питательности), усвояемость протеина у молодняка после 6-месячного возраста оказалась в несколько раз выше, чем при рационах с малым количеством сочных кормов.

Чрезмерные дачи (около 60-70\% по общей питательности рационов) корнеплодов снижали использование протеина и потребление сена и были причиной отрицательных балансов азота. Наилучшие диэтические каче- 
ства имели зимние рационы, содержавшие смесь сочных кормов - корнеплоды, силос, картофель (30-40\% по общей питательности) и достаточное количество хорошего сена.

На усвояемость протеина и биологическую ценность рационов большое влияние оказывал уровень общего и протеинового кормления и степень интенсивности развития молодняка.

\section{Ннститут животноводства и ветеринарии Академии наук Эстонской ССР}

Поступила в редакцию 24 IX 1954

\section{ЛИТЕРАТУРА}

1. П. Я. Аранди, Переваримость питательных веществ рацнонов молодняком эстонской красной породы в зависимости от типа и уровня кормления, «Известия Академии наук Эстонской ССР», т. III, № 3, 1954.

2. А. А. Атбашьян, Изменения в организме молодняка крупного рогатого скота под влиянием разных типов питания, Диссертация, Москва, 1949.

3. П. В. Д емченко, Азотистый и фосфорно-кальциевый обмен у телят разного возраста при различном уровне белкового питания, Сборник работ по изучению питательной ценности и использованию кормовых средств, Вологда, 1941.

4. В. П. Демьян чук, Влияние уровня питания молочным жиром на обмен веществ телят, Диссертация, Харьков, 1953.

5. А. П. Д ми т роченко, K вопросу о методах изучения действия корма на растущих животных, Известия Государственного института опытной агрономии, т. 6, № 3-4, 1926.

6. Л. И. Д ракин, Обмен веществ и энергии у телят, Труды Всесоюзного научноисследовательского института животноводства, т. 18, Сельхозгиз, Москва, 1950.

7. А. А. З агриш ев, Молочный жнр в питании телят раннего возраста, Диссертация, Москва, 1949.

8. Е. Н. И в ицк а я, Влияние характера кормления телок на их развитие, обмен веществ и последующую молочную продуктивность, Диссертация, Харьков, 1953.

9. М. В. Мыс юткина, Н. А. С авелова и М. П. Сементовский, Обмен кальщня, фосфора и азота у телят холмогорской породы при различном уровне минерального питания, «Вестник животноводства», вып. 2, 1946.

10. И. С. Попов, Кормление сельскохозяйственных животных, Сельхозгиз, Москва, 1951.

11. П. Д. Пшен и чны й, Материалы к учению о воспитании молодняка сельскохозяйственных животных, Диссертация, Харьков, 1947.

12. Е. Г. С вешников а, Влияние относительной витаминной ценности молока на рост и азотистый обмен у телят, Записки Детскосельской опытной зоотехнической станции Ленинградского сельскохозяйственного института, вып. 6, Ленинград, 1929. .

13. Е. А. Соколов, Обмен азота и кальция у телят в молочный период, «Научноагрономический журнал», № 5-6, 1929 .

14. Д. А. Т опилин, Выращивание высокопродуктивных сибирско-остфризских помесей на разных типах кормовых рационов, Диссертация, Москва-Омск, 1953.

15. Т. С. Щекотова, Влияние типа воспитания красного степного скота и его помесей на развитие, продуктивность и использование кормов, Диссертация, Аскания-Нова, 1952. 